\title{
Peningkatan Berpikir Kritis dan Prestasi Belajar Melalui Metode Inquiry pada Siswa Kelas IV SD
}

\author{
L. Lastriningsih \\ SD Kasongan. Jalan Raya Kasongan, Bangunjiwo, Kasihan, Bantul, Yogyakarta 55184, Indonesia \\ Korespondensi Penulis. Email: lastriningsih46@gmail.com, \\ Received: 6 January 2016; Revised:26 January 2016; Accepted: 29 January 2016
}

\begin{abstract}
Abstrak
Penelitian ini bertujuan meningkatkan kemampuan berpikir kritis dan prestasi belajar pada ranah pengetahuan, sikap, dan keterampilan melalui metode inquiry pada pembelajaran tematikintegratif siswa kelas IV SD Kasongan Bantul. Penelitian ini adalah penelitian tindakan kelas (PTK) yang dilaksanakan dalam tiga siklus. Setiap siklus terdiri atas dua pertemuan. Subjek penelitian adalah siswa kelas IV SD Kasongan Bantul sebanyak 20 siswa. Teknik pengumpulan data yang digunakan adalah tes, dan observasi. Instrumen yang digunakan adalah soal tes uraian, pilihan ganda, dan rating scale. Hasil penelitian menunjukkan bahwa penerapan metode inquiry pada pembelajaran tematik integratif dapat meningkatkan kemampuan berpikir kritis dan prestasi belajar dalam ranah pengetahuan, sikap, dan keterampilan.
\end{abstract}

Kata Kunci: berpikir kritis, prestasi belajar, metode inquiry

\section{Improving Critical Thinking and Learning Achievement Through Inquiry Method of Grade IV Elementary School}

\begin{abstract}
This study aims to improve the ability of critical thinking and learning achievement in terms of knowledge, attitudes, and skills through inquiry method on integrated thematic learning of the fourth grade students of Elementary School Kasongan Bantul. This research was classroom action research (CAR) which was implemented in three cycles. Each cycle consisted of two meetings. The subjects were 20 grade IV students of Elementary School Kasongan Bantul. Data collection techniques used were tests, and observations. The instruments used were an essay test, multiple choice test, and rating scale. The results show that the application of the inquiry method on thematic integrative learning can improve critical thinking skills and learning achievement in terms of knowledge, attitudes, and skills.
\end{abstract}

Keywords: critical thinking, learning achievement, inquiry method

How to Cite: Lastriningsih, L. (2017). Peningkatan berpikir kritis dan prestasi belajar melalui metode inquiry pada siswa kelas IV SD.Jurnal Prima Edukasia, 5(1), 68-78. doi:http://dx.doi.org/10.21831/jpe.v5i1.7714

Permalink/DOI: http://dx.doi.org/10.21831/jpe.v5i1.7714 


\section{Pendahuluan}

Undang-Undang Nomor 20 Tahun 2003 tentang Sistem Pendidikan Nasional menyatakan bahwa tujuan pendidikan nasional adalah untuk berkembangnya potensi peserta didik agar menjadi manusia yang beriman dan bertakwa kepada Tuhan Yang Maha Esa, berakhlak mulia, sehat, berilmu, cakap, kreatif, mandiri, dan menjadi warga negara yang demokratis serta bertanggung jawab. Untuk mencapai tujuan tersebut, pada tahun pelajaran 2014/2015 pemerintah menginstruksikan semua sekolah agar mengimplementasikan kurikulum 2013. Prinsip pembelajaran dalam kurikulum 2013 adalah pembelajaran tematik integratif dengan pendekatan saintifik.

Setyawan \& Mustadi (2015, p. 109) menyatakan bahwa pembelajaran tematik di sekolah dasar merupakan terapan dari pembelajaran terpadu yaitu dengan mengintegrasikan beberapa aspek, baik dalam mata pelajaran maupun antar mata pelajaran. Pengintegrasian beberapa aspek mata pelajaran membawa siswa memperoleh pengetahuan secara utuh. Melalui pembelajaran tematik integratif tersebut, pembelajaran akan lebih memberi makna bagi siswa.

Terkait dengan pengintegrasian Wangid, Mustadi, Erviana, \& Arifin (2014, p. 117) menyatakan bahwa pengintegrasian tersebut dilakukan dalam dua hal, yaitu integrasi sikap, keterampilan, dan pengetahuan dalam proses pembelajaran dan integrasi berbagai konsep dasar yang berkaitan. Tema ini menjadi alat pemersatu materi yang beragam dari berbagai mata pelajaran.

Matematika sebagai salah satu muatan dalam kurikulum 2013 merupakan ilmu dasar yang mempunyai peran penting dalam perkembangan ilmu pengetahuan dan teknologi. Muijs \& Reynolds (2005, p.212) mengemukakan bahwa matematika adalah mata pelajaran mengembangkan kemampuan berpikir logis dan kemampuan kognitif tingkat tinggi serta merupakan ilmu dasar yang berperan dalam ilmuilmu yang lain. Matematika perlu diberikan kepada siswa sekolah dasar untuk membekali kemampuan berpikir logis, kritis, kreatif, dan kemampuan bekerjasama.

Kompetensi pembelajaran dapat dicapai melalui berbagai aktivitas yang berbeda. Aktivitas-aktivitas tersebut dapat dikembangkan melalui beberapa keterampilan berpikir, seperti berpikir kritis, berpikir kreatif, dan pemecahan masalah. Berpikir kritis merupakan salah satu kecakapan yang perlu dikembangkan dalam proses pendidikan. McGregor (2007, p.209) mengemukakan bahwa berpikir kritis merupakan tindakan mental yang berupa meninjau dan mengevaluasi atau menilai sesuatu dalam upaya untuk membuat penilaian dan kesimpulan secara rasional dan beralasan. Hal ini berarti dengan berpikir kritis memungkinkan siswa mengevaluasi bukti-bukti dalam upaya membuat kesimpulan yang rasional.

Kemampuan berpikir kritis dapat dikembangkan melalui kegiatan menganalisis dan mengevaluasi. Pernyataan ini didukung oleh (Anindyta \& Suwarjo, 2014, p. 210)yang menyatakan bahwa siswa dapat mengembangkan kemampuan berpikir kritis melalui serangkaian kegiatan menganalisis dan mengevaluasi. Dengan keterlibatan siswa dalam menganalisis dan mengevaluasi pengetahuan merupakan sarana untuk mengembangkan kemampuan berpikir kritis.

Aspek kemampuan berpikir kritis meliputi mengidentifikasi masalah, menganalisis, dan menyimpulkan. Mengidentifikasi masalah berarti mampu merumuskan pokok-pokok permasalahan. Menganalisis berarti mampu menghubungkan informasi yang relevan dalam penyelesaian suatu masalah. Sedangkan Menyimpulkan berarti mampu menyusun kesimpulan berdasarkan hasil analisis.

Setiap orang dapat menumbuhkan kemampuan berpikir kritis karena otak manusia secara konstan berusaha memahami pengalaman. Schneider (2002, p.2) menyatakan bahwa siswa sekolah dasar memiliki pengalaman yang mengejutkan dan kompleks serta sering memiliki wawasan di luar dugaan guru. Siswa SD telah memiliki pengalaman dan pengetahuan yang kompleks sebagai bekal dalam berpikir kritis. Namun, dalam melatih kemampuan berpikir kritis pada siswa SD harus disesuaikan dengan perkembangan pengetahuannya.

Duron, Limbach, \& Waugh (2006, p. 160) menyatakan bahwa pembelajaran aktif menjadikan pembelajaran lebih menyenangkan bagi guru dan siswa, dan yang paling penting dapat menyebabkan siswa untuk berpikir kritis. Pembelajaran yang aktif adalah pembelajaran yang berpusat kepada siswa (student centered). Pada proses pembelajaran yang berpusat kepada siswa, siswa aktif mengkonstruksi pengetahuannya sendiri berdasarkan pengalaman dan pengetahuan yang telah dimilikinya dengan bimbingan guru. 
Kemampuan manusia untuk menggunakan akalnya merupakan potensi dasar yang memungkinkan manusia belajar. Winkel (2014, p.59) mendefinisikan belajar sebagai suatu proses psikis yang berlangsung dalam interaksi aktif dengan lingkungannya, yang menghasilkan sejumlah perubahan dalam pengetahuan, pemahaman, keterampilan, nilai, dan sikap yang bersifat konstan/berbekas. Keberhasilan suatu proses belajar ditunjukkan dengan prestasi belajar. Stiggins \& Chappuis (2008, p.35) menyatakan bahwa prestasi atau target belajar merupakan gambaran keberhasilan akademis. Prestasi belajar dapat menjadi gambaran keberhasilan proses pembelajaran yang telah dilakukan.

Proses belajar tidak bersifat tunggal, namun melibatkan beberapa ranah belajar yang saling berkaitan. Prestasi belajar pada pembelajaran tematik integratif mencakup ranah pengetahuan, sikap, dan keterampilan. Orlich, et.al., (2009, p.66) menyatakan bahwa ranah pengetahuan mencakup tujuan yang berhubungan dengan pengingatan atau pengenalan pengetahuan dan pengembangan kemampuan intelektual dan keterampilan. Sedangkan ranah sikap merupakan kecenderungan untuk merespon dunia sekitarnya baik yang berupa individu maupun objek tertentu. Dalam kurikulum 2013, sikap dibagi menjadi dua jenis yaitu sikap spiritual dan sikap sosial. Ranah keterampilan adalah ranah yang berkaitan dengan keterampilan (skill) atau kemampuan bertindak setelah seseorang menerima pengalaman belajar tertentu (Kunandar, 2013, p.249). Dalam kurikulum 2013 ranah keterampilan mencakup keterampilan pikir dan tindak dalam ranah konkret dan abstrak.

Siswa sekolah dasar berada pada tahap operasional konkret (Piaget dalam Schunk, 2012, p.339). Oleh karena itu, pembelajaran harus dilakukan sesuai dengan karakteristik siswa supaya dapat mempermudah pencapaian tujuan pembelajaran. Tujuan pembelajaran di sekolah dasar lebih ditekankan pada penanaman konsep awal. Penanaman konsep tersebut harus dilakukan dengan baik karena pemahaman konsep akan berpengaruh pada penguasaan kompetensi pada tingkatan pendidikan selanjutnya. Salah satu metode pembelajaran yang dapat diterapkan dalam pembelajaran siswa SD adalah dengan metode pembelajaran inquiry. Kindsvatter, et.al. (1996, p.258) menyatakan bahwa metode inquiry adalah sebuah proses di mana siswa dapat belajar dan bereksperimen seperti mereka sedang menyelesaikan permasa- lahan melalui berpikir reflektif. Metode inquiry merupakan proses belajar penyelesaian masalah melalui berpikir reflektif. Langkah-langkah inquiry tersebut meliputi mengidentifikasi masalah, menyelesaikan masalah, mengomunikasikan, mengaplikasikan, dan mengevaluasi.

Tingkatan inquiry yang sesuai untuk siswa usia sekolah dasar adalah inquiry terstruktur (structured inquiry). (Banchi \& Bell, 2008, p. 26) mengemukakan bahwa siswa SD belum bisa merancangdan melaksanakan penyelidikan sendiri. Untuk dapat melakukan penyelidikan secara mandiri diperlukan latihan kemampuan penyelidikan secara terus-menerus. Pada tingkatan inquiry terstruktur pembelajaran berfokus pada penyelidikan suatu fenomena yang menarik perhatian siswa. Siswa menyelidiki pertanyaan yang disajikan guru melalui prosedur yang ditentukan. Siswa harus menemukan dengan menghubungkan dan menggeneralisasikan data yang dikumpulkan. Pembelajaran berfokus pada pemahaman siswa terhadap kesimpulan yang disusunnya.

Metode pembelajaran inquiry dapat meningkatkan kemampuan untuk menjelaskan pemikiran dalam memahami konsep-konsep sehingga kemampuan berpikir kritis dan prestasi belajar dapat meningkat. Hal ini sesuai dengan hasil penelitian yang dilakukan (Brown, Wilson, \& Fitzallen, 2007) berjudul "Using an Inquiry Approach to Develop Mathematical Thinking". Penelitian ini menemukan bahwa dengan metode pembelajaran inquiry, siswa mampu meningkatkan kemauan dan kemampuan untuk menjelaskan pemikiran mereka.

Namun berdasarkan hasil observasi di SD Kasongan Bantul pada awal bulan Oktober 2014 diketahui bahwa selama ini proses pembelajaran di kelas masih diarahkan pada kemampuan untuk menerima informasi, kemampuan siswa masih difokuskan untuk mengingat dan menghafal materi pelajaran. Hal ini menyebabkan kemampuan berpikir kritis siswa belum terlatih secara optimal. Hasil tes matematika yang berhubungan dengan berpikir kritis menunjukkan bahwa kemampuan berpikir kritis pada muatan matematika masih masuk dalam kategori rendah, yaitu hanya sebesar $50 \%$.

Selain masalah rendahnya kemampuan berpikir kritis, prestasi belajar matematika di kelas IVSD Kasongan juga masih rendah. Nilai rata-rata kelas dan persentase ketuntasan belajar siswa pada Ulangan Akhir Semester untuk kompetensi pembelajaran matematika selama 2 
tahun berturut-turut tergolong rendah. Rendahnya prestasi belajar matematika juga ditunjukkan pada pembelajaran tematik integratif pada tahun pelajaran 2014/2015. Hasil ulangan tengah semester I menunjukkan rendahnya persentase ketuntasan belajar pada muatan matematika. Persentase ketuntasan pada ranah sikap sebesar $75 \%$, pada ranah pengetahuan ketuntasan hanya sebesar $50 \%$, dan pada ranah keterampilan ketuntasan juga baru sebesar $60 \%$. Beberapa materi matematika yang sering dirasa sulit oleh siswa di kelas IV, diantaranya adalah materi pecahan, desimal dan persen. Penyebab kesulitan pada materi desimal dan persen dikarenakan kesalahan anggapan siswa tentang nilai desimal dan persen.

Dari berbagai permasalahan kelas tersebut, maka penelitian ini memfokuskan pada masalah rendahnya kemampuan berpikir kritis dan prestasi belajar matematika pada ranah pengetahuan, sikap, dan keterampilan pada pembelajaran tematik integratif siswa kelas IV SD Kasongan Bantul khususnya pada materi desimal dan persen. Adanya permasalahan kelas tersebut maka perlu adanya penyelesaian. Penyelesaian masalah tersebut dirumuskan dalam rumusan masalah yaitu, yang pertama bagaimana peningkatan kemampuan berpikir kritis melalui pembelajaran dengan metode inquiry pada pembelajaran tematik integratif siswa kelas IV SD Kasongan Bantul? Kedua, bagaimana peningkatan prestasi belajar matematika pada ranah pengetahuan, sikap, dan keterampilan melalui pembelajaran dengan metode inquiry pada pembelajaran tematik integratif siswa kelas IV SD Kasongan Bantul?

Penelitian ini bertujuan untuk meningkatkan kemampuan berpikir kritis dan prestasi belajar matematika pada ranah pengetahuan, sikap, dan keterampilan melalui melalui metode inquiry pada pembelajaran tematik integratif siswa kelas IV SD Kasongan Bantul. Ada beberapa hal yang dapat diambil manfaat dari penelitian ini, yaitu bagi siswa, guru, dan sekolah. Manfaat bagi siswa yaitu meningkatkan kemampuan menganalisis dan menyelesaikan suatu permasalahan berdasarkan fakta yang ada, memberi pemahaman tentang materi desimal dan persen melalui penemuan konsep yang dilakukannya sendiri, dan memberi pengalaman nyata dalam pembelajaran, sehingga siswa diharapkan mampu mengaplikasikan kemampuan dan pengetahuan yang diperolehnya dalam kehidupan sehari-hari. Manfaat penelitian ini bagi guru antara lain membantu guru mengatasi permasalahan pembelajaran di kelas, membantu guru dalam meningkatkan kemampuan berpikir kritis siswa, membantu guru dalam meningkatkan prestasi belajar matematika siswa, menambah wawasan guru di bidang pendidikan khususnya dalam penerapan metode pembelajaran inquiry pada pembelajaran tematik integratif. Sedangkan manfaat bagi sekolah adalah meningkatkan kualitas dan prestasi belajar matematika siswa di sekolah dan memberi sumbangan pemikiran dalam rangka mencapai tujuan pendidikan nasional.

\section{Metode}

Jenis penelitian yang digunakan adalah Penelitian Tindakan Kelas (PTK) dengan desain PTK model Kemmis \& McTaggart. Tahap dalam setiap siklus terdiri atas empat kegiatan dalam tiga tahap yang terdiri atas perencanaan (plan), tindakan dan pengamatan (act and observe), dan refleksi (reflect). Dari hasil refleksi disusun sebuah modifikasi yang diaktualisasikan dalam siklus berikutnya. Visualisasi desain PTK model Kemmis \& McTaggart disajikan dalam bagan berikut ini.

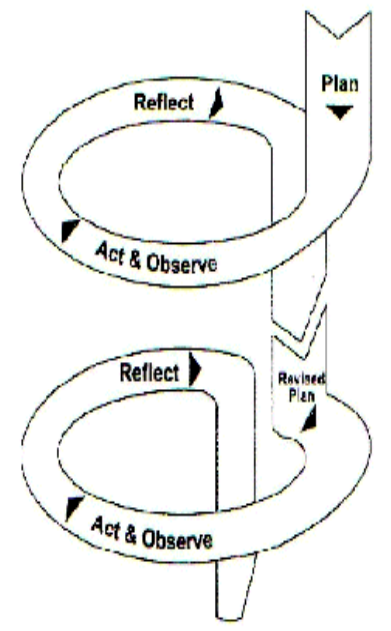

Gambar 1. Siklus PTK model Kemmis \& McTaggart (McTaggart, 1991, p.32)

Keterangan:

1. Plan: merencanakan tindakan

2. Act and observe: melakukan dan mengamati tindakan

3. Reflect: mengevaluasi tindakan

Penelitian ini dilakukan pada bulan Desember 2014 sampai dengan Januari 2015. Penelitian ini dilakukan di kelas IV SD Kasongan, Kecamatan, Kasihan, Kabupaten Bantul. Subjek penelitian adalah siswa kelas IV SD Kasongan pada Tahun Pelajaran 2014/2015. Siswa kelas IV berjumlah 20 siswa terdiri atas 
11 laki-laki dan 9 perempuan. Siswa tersebut berusia antara 9 tahun sampai dengan 11 tahun.

Siklus dalam PTK ini terdiri atas empat kegiatan dalam tiga langkah yaitu plan (perencanaan), act and observe (pelaksanaan dan pengamatan), dan (reflect) refleksi. Pada tahap plan (perencanaan) guru menyusun perangkat pembelajaran dan instrumen penelitian. Pada tahap pelaksanaan, kegiatan pembelajaran dilakukan sesuai langkah-langkah inquiry yaitu mengidentifikasi masalah, menyelesaikan masalah, mengomunikasikan, mengaplikasikan, dan mengevaluasi. Kegiatan observasi atau pengamatan dilakukan selama pelaksanaan tindakan. Observasi dilakukan oleh dua observer yaitu peneliti sebagai observer I dan guru senior sebagai observer II. Pengamatan difokuskan pada keterlaksanaan pembelajaran dengan metode inquiry dan sikap yang ditunjukkan siswa selama pembelajaran. Pada tahap refleksi dilakukan diskusi antara peneliti dan guru kolaborator dengan maksud untuk mengevaluasi hasil pembelajaran yang telah berlangsung dan merumuskan perencanaan berikutnya. Hasil refleksi atas kekurangan yang terjadi pada siklus sebelumnya dijadikan sebagai acuan dalam perbaikan rencana tindakan pada siklus selanjutnya.

Teknik pengumpulan data yang digunakan dalam penelitian ini adalah tes dan non tes. Tes digunakan untuk mendapatkan data tentang kemampuan berpikir kritis, prestasi belajar ranah pengetahuan dan prestasi belajar ranah keterampilan. Sedangkan teknik nontes digunakan untuk mengetahui keterlaksanaan pembelajaran dan sikap siswa selama pembelajaran. Instrumen pengumpul data pada penelitian ini meliputi soal tes pilihan ganda, soal tes uraian kemampuan berpikir kritis, soal tes uraian keterampilan pemecahan masalah, rating scale sikap, dan rating scale keterlaksanaan pembelajaran.

Kriteria keberhasilan tindakan pada penelitian ini yaitu keterlaksanaan pembelajaran dengan metode inquiry telah mencapai kategori minimal Baik, sebanyak $\geq 75 \%$ siswa memiliki kemampuan berpikir kritis dengan kategori minimal Baik, sebanyak $\geq 75 \%$ siswa memiliki nilai prestasi belajar ranah pengetahuan dengan kategori minimal Baik, sebanyak $\geq 75 \%$ siswa memiliki nilai prestasi belajar ranah psikap dengan kategori minimal Baik, dan sebanyak $\geq 75 \%$ siswa memiliki nilai prestasi belajar ranah keterampilan dengan kategori minimal Baik. Penelitian ini dihentikan jika seluruh kriteria keberhasilan tersebut tercapai.
Data dalam penelitian ini dianalisis secara kuantitatif dan kualitatif. Data yang berupa hasil tes dianalisis secara kuantitatif dengan menghitung rata-rata, ketuntasan individual dan klasikal. Sedangkan data hasil observasi dianalisis secara kualitatif.

\section{Hasil dan Pembahasan}

\section{Siklus I}

Hasil pengamatan keterlaksanaan pembelajaran menunjukkan persentase keterlaksanaan pembelajaran sebesar $81,51 \%$, sehingga masuk dalam kategori Baik. Secara umum proses pembelajaran pada siklus I telah baik, guru telah mengajukan persoalan yang diselidiki dengan sangat baik. Namun pada pertemuan pertama, guru masih kurang dalam memotivasi siswa untuk menanggapi penjelasan kelompok lain, sehingga siswa kurang aktif dalam menanggapi penjelasan kelompok lain.

Hasil tes kemampuan berpikir kritis pada siklus I menunjukkan nilai rata-rata siswa sebesar 2,71 sedangkan persentase ketuntasan siswa sebesar 55\%. Nilai tertinggi yang diperoleh 4,00 dan nilai terendah 1,67 seperti yang terlihat pada Tabel 1.

Tabel 1. Nilai Tes Berpikir Kritis Siklus I

\begin{tabular}{cc}
\hline Keterangan & Nilai Siklus I \\
\hline Nilai tertinggi & 4,00 \\
Nilai terendah & 1,67 \\
Rata-rata nilai & 2,71 \\
Persentase ketuntasan & $55 \%$ \\
\hline
\end{tabular}

Aspek kemampuan berpikir kritis meliputi mengidentifikasi masalah, menganalisis, dan menyimpulkan. Pada aspek mengidentifikasi masalah persentase ketuntasan kelas sebesar $70 \%$. Pada aspek menganalisis persentase ketuntasan kelas hanya $60 \%$. Sedangkan persentase ketuntasan pada aspek menyimpulkan sebesar $60 \%$.

Tabel 2. Ketuntasan Aspek Berpikir Kritis Siklus I

\begin{tabular}{lc}
\hline \multicolumn{1}{c}{ Aspek } & Persentase \\
\hline Mengidentifikasi masalah & $70 \%$ \\
Menganalisis & $60 \%$ \\
Menyimpulkan & $60 \%$ \\
\hline
\end{tabular}

Hasil tes prestasi belajar pada siklus I menunjukkan nilai rata-rata sebesar 2,71 dengan persentase ketuntasan siswa $65 \%$. Nilai tertinggi yang diperoleh 3,47 dan nilai terendah 1,60 seperti yang terlihat pada Tabel 3 . 
Tabel 3. Nilai Tes Prestasi Belajar Siklus I

\begin{tabular}{cc}
\hline Keterangan & Nilai Siklus I \\
\hline Nilai tertinggi & 3,47 \\
Nilai terendah & 1,60 \\
Rata-rata nilai & 2,71 \\
Persentase ketuntasan & $65 \%$ \\
\hline
\end{tabular}

Hasil observasi sikap siswa pada siklus I menunjukkan rata-rata skor sikap sebesar 2,84 sedangkan persentase ketuntasan siswa sebesar $65 \%$ seperti yang terlihat pada tabel 4 berikut.

Tabel 4. Hasil Observasi Sikap Siklus I

\begin{tabular}{cc}
\hline Keterangan & Nilai Siklus I \\
\hline Rata-rata skor & 2,84 \\
Persentase ketuntasan & $65 \%$ \\
\hline
\end{tabular}

Hasil tes keterampilan pemecahan masalah pada siklus I menunjukkan nilai rata-rata siswa 2,75 sedangkan persentase ketuntasan siswa sebesar $70 \%$. Nilai tertinggi yang diperoleh 3,81 dan nilai terendah 1,75 seperti yang terlihat pada Tabel 5 .

Tabel 5. Nilai Tes Keterampilan Siklus I

\begin{tabular}{cc}
\hline Keterangan & Nilai Siklus I \\
\hline Nilai tertinggi & 3,81 \\
Nilai terendah & 1,75 \\
Rata-rata nilai & 2,75 \\
Persentase ketuntasan & $70 \%$ \\
\hline
\end{tabular}

Refleksi dilakukan setelah pelaksanaan pembelajaran dengan hasil sebagai berikut. Kerja sama dalam kelompok masih kurang sehingga guru perlu memberikan penjelasan kepada siswa tentang pentingnya kerja sama dalam kelompok. Ada beberapa siswa yang kesulitan dalam melakukan kegiatan penyelidikan, sehingga guru perlu memantau siswa dalam melakukan kegiatan. Siswa juga masih kesulitan dalam menganalisis dan menyusun kesimpulan sehingga guru perlu memberikan bimbingan. Selain itu, siswa kurang aktif dalam diskusi kelas sehingga guru perlu memotivasi siswa untuk mengemukakan ide dengan cara memberikan reward.

\section{Siklus II}

Hasil pengamatan keterlaksanaan pembelajaran menunjukkan persentase keterlaksanaan pembelajaran sebesar $84,13 \%$, sehingga masuk dalam kategori Baik. Secara umum proses pembelajaran pada siklus II telah baik, namun beberapa siswa masih kesulitan dalam menganalisis dan menyusun kesimpulan.

Hasil tes kemampuan berpikir kritis pada siklus II menunjukkan nilai rata-rata siswa 2,89 dengan persentase ketuntasan sebesar $70 \%$. Nilai tertinggi yang diperoleh 4,00 dan nilai terendah 1,67 seperti yang terlihat pada Tabel 6 .

Tabel 6. Nilai Tes Berpikir Kritis Siklus II

\begin{tabular}{cc}
\hline Keterangan & Nilai Siklus II \\
\hline Nilai tertinggi & 4,00 \\
Nilai terendah & 1,67 \\
Rata-rata nilai & 2,89 \\
Persentase ketuntasan & $70 \%$ \\
\hline Persentase ketuntasan & kemampuan ber-
\end{tabular}
pikir kritis pada aspek mengidentifikasi masalah sebesar $80 \%$. Pada aspek menganalisis hanya sebesar70\%. Sedangkan persentase ketuntasan pada aspek menyimpulkan sebesar $60 \%$. Seperti yang terlihat pada Tabel 7.

Tabel 7. Ketuntasan Aspek Berpikir Kritis Siklus II

\begin{tabular}{cc}
\hline Aspek & Persentase \\
\hline Mengidentifikasi masalah & $80 \%$ \\
Menganalisis & $70 \%$ \\
Menyimpulkan & $60 \%$ \\
\hline
\end{tabular}

Hasil tes prestasi belajar pada siklus II menunjukkan nilai rata-rata siswa 2,88 persentase ketuntasan siswa sebesar $75 \%$. Nilai tertinggi yang diperoleh 3,73 dan nilai terendah 1,60 seperti yang terlihat pada Tabel 8 .

Tabel 8. Nilai Tes Prestasi Belajar Siklus II

\begin{tabular}{cc}
\hline Keterangan & Nilai Siklus II \\
\hline Nilai tertinggi & 3,73 \\
Nilai terendah & 1,60 \\
Rata-rata nilai & 2,88 \\
Persentase ketuntasan & $75 \%$ \\
\hline
\end{tabular}

Hasil observasi sikap siswa pada siklus II menunjukkan skor rata-rata siswa sebesar 3,00 sedangkan persentase ketuntasan siswa sebesar $80 \%$ seperti yang terlihat pada Tabel 9 .

Tabel 9. Hasil Observasi Sikap Siklus II

\begin{tabular}{cc}
\hline Keterangan & Nilai Siklus II \\
\hline Rata-rata skor & 3,00 \\
Persentase ketuntasan & $80 \%$ \\
\hline Hasil tes keterampilan pemecahan masa-
\end{tabular}
lah pada siklus II menunjukkan nilai rata-rata 2,98 dengan persentase ketuntasan $75 \%$. Nilai tertinggi yang diperoleh 4,00 dan nilai terendah 1,88 seperti terlihat pada Tabel 10.

Tabel 10. Nilai Tes Keterampilan Siklus II

\begin{tabular}{cc}
\hline Keterangan & Nilai Siklus II \\
\hline Nilai tertinggi & 4,00 \\
Nilai terendah & 1,88 \\
Rata-rata nilai & 2,98 \\
Persentase ketuntasan & $75 \%$ \\
\hline
\end{tabular}


Refleksi dilakukan setelah setelah pelaksanaan pembelajaran dengan hasil sebagai berikut. Ada beberapa siswa yang masih pasif dalam diskusis kelompok sehingga guru perlu memberikan motivasi kepada siswa untuk bekerja sama dalam diskusi kelompok. Siswa juga terlihat belum sistematis dalam menganalisis data sehingga kesulitan menyusun kesimpulan hasil penyelidikan maka guru perlu mendorong siswa untuk menganalisis permasalahan secara lebih sistematis agar lebih mudah membuat kesimpulan.

\section{Siklus III}

Hasil pengamatan keterlaksanaan pembelajaran menunjukkan persentase keterlaksanaan pembelajaran sebesar $87,50 \%$, sehingga masuk dalam kategori Baik. Hasil tes kemampuan berpikir kritis pada siklus III menunjukkan nilai rata-rata siswa 3,12 sedangkan persentase ketuntasan siswa sebesar $80 \%$. Nilai tertinggi yang diperoleh 4,00 dan nilai terendah 1,78 terlihat pada Tabel 11 .

Tabel 11. Nilai Tes Berpikir Kritis Siklus III

\begin{tabular}{cc}
\hline Keterangan & Nilai Siklus III \\
\hline Nilai tertinggi & 4,00 \\
Nilai terendah & 1,78 \\
Rata-rata nilai & 3,12 \\
Persentase ketuntasan & $80 \%$ \\
\hline
\end{tabular}

Pada aspek mengidentifikasi masalah persentase ketuntasan kelas sebesar 95\%. Pada aspek menganalisis persentase ketuntasan kelas sebesar $80 \%$. Sedangkan persentase ketuntasan pada aspek menyimpulkan sebesar $75 \%$.

Tabel 12. Ketuntasan Aspek Berpikir Kritis Siklus III

\begin{tabular}{cc}
\hline Aspek & Persentase \\
\hline Mengidentifikasi masalah & $95 \%$ \\
Menganalisis & $80 \%$ \\
Menyimpulkan & $75 \%$ \\
\hline
\end{tabular}

Hasil tes prestasi belajar pada siklus III menunjukkan nilai rata-rata siswa sebesar 3,04 sedangkan persentase ketuntasan siswa sebesar $80 \%$. Nilai tertinggi yang diperoleh 4,00 dan nilai terendah 1,87 seperti yang terlihat pada Tabel 13.

Tabel 13. Nilai Tes Prestasi Belajar Siklus III

\begin{tabular}{cc}
\hline Keterangan & Nilai Siklus III \\
\hline Nilai tertinggi & 4,00 \\
Nilai terendah & 1,87 \\
Rata-rata nilai & 3,04 \\
Persentase ketuntasan & $80 \%$ \\
\hline
\end{tabular}

Hasil observasi sikap siswa pada siklus III menunjukkan skor rata-rata siswa sebesar 3,16 sedangkan persentase ketuntasan siswa sebesar $90 \%$.

Tabel 14. Hasil Observasi Sikap Siklus III

\begin{tabular}{cc}
\hline Keterangan & Nilai Siklus III \\
\hline Rata-rata skor & 2,16 \\
Persentase ketuntasan & $90 \%$ \\
\hline
\end{tabular}

Hasil tes keterampilan pemecahan masalah pada siklus III menunjukkan nilai rata-rata sebesar 3,20 sedangkan persentase ketuntasan siswa sebesar $80 \%$. Nilai tertinggi yang diperoleh 4,00 dan nilai terendah 2,13 seperti yang terlihat pada Tabel 15.

Tabel 15. Nilai Tes Keterampilan Siklus III

\begin{tabular}{cc}
\hline Keterangan & Nilai Siklus III \\
\hline Nilai tertinggi & 4,00 \\
Nilai terendah & 2,13 \\
Rata-rata nilai & 3,20 \\
Persentase ketuntasan & $80 \%$ \\
\hline Refleksi dilakukan setelah pelaksanaan
\end{tabular}
pembelajaran dengan hasil sebagai berikut. Siswa telah terbiasa melakukan kegiatan inquiry sehingga kegiatan inquiry terlihat berjalan lebih lancar. Siswa juga terlihat lebih aktif menanggapi hasil diskusi dan membuat kesimpulan secara bersama-sama. Selain itu, siswa terlihat menganalisis data secara lebih sistematis sehingga mudah menyusun kesimpulan dari kegiatan yang dilakukannya. Pelaksanaan tindakan pada siklus III telah mencapai kriteria keberhasilan sehingga tidak diperlukan tindakan selanjutnya.

Pembahasan

Pelaksanaan metode inquiry pada pembelajaran tematik integratif meliputi kegiatan mengidentifikasi masalah, menyelesaikan masalah, mengomunikasikan, mengaplikasikan, dan mengevaluasi. Dari hasil observasi siklus I, keterlaksanaan pembelajaran baru sebesar $81,51 \%$. Pembelajaran sudah masuk dalam kategori baik, namun guru masih kurang dalam memotivasi siswa untuk aktif dalam kegiatan penyelidikan dan diskusi kelompok. Pada siklus II guru memberikan motivasi dengan reward berupa pin berbentuk bintang kepada kelompok yang aktif dalam pembelajaran. Siswa terlihat termotivasi untuk mendapatkan reward sehingga mereka aktif dalam pembelajaran di kelas.

Keterlaksanan pembelajaran pada siklus II meningkat menjadi $84,13 \%$. Namun, pada siklus II siswa masih kesulitan dalam meng- 
analisis dan menyimpulkan hasil penyelidikan. Berdasarkan masalah ini maka pada siklus III guru memberikan bimbingan dan motivasi agar siswa menganalisis informasi yang didapatkan secara lebih sistematis. Keterlaksanaan pembelajaran pada siklus III mencapai $87,50 \%$. Siswa terlihat mampu mengidentifikasi masalah, menyelesaikan masalah secara lebih sistematis sehingga tidak mengalami kesulitan dalam menyusun kesimpulan.

Dalam pembelajaran yang telah dilaksanakan langkah-langkah kegiatan Inquiry sesuai dengan karakteristik metode pembelajaran inquiry yang diyatakan oleh Dell'Olio \& Donk (2007, p.320) bahwa discovery learning, Inquiry-based learning, and problem-based learning menggambarkan pengalaman siswa ketika berjuang menghadapi pertanyaan atau masalah dan mengkomunikasikan informasi yang di temukan kepada orang lain.

Selain itu, guru berperan dalam membimbing dan memotivasi siswa untuk membangun sendiri pengetahuannya. Guru mengorganisir semua unsur pembelajaran dan mengarahkannya pada suasana yang memungkinkan siswa untuk belajar, sehingga kompetensi yang diharapkan dapat tercapai. Hal ini menunjukkan bahwa guru memegang peran sebagai motivator dan fasilitator, bukan sebagai pentransfer pengetahuan. Hal ini sesuai dengan pendapat Hosnan (2014, p.341) bahwa pembelajaran inquiry menekankan sesuai pada proses mencari dan menemukan. Siswa mencari dan menemukan sendiri pengetahuan dari kegiatan belajar, sedangkan guru berperan sebagai fasilitator dan pembimbing siswa untuk belajar.

Kemampuan berpikir kritis dan prestasi belajar yang difokuskan dalam penelitian ini juga mengalami peningkatan. Hasil tes pada siklus I menunjukkan persentase ketuntasan kemampuan berpikir kritis sebesar 55\% yang masih termasuk kategori sedang. Pada siklus II persentase ketuntasan menjadi $70 \%$ namun masih termasuk kategori sedang. Sedangkan pada siklus III persentase ketuntasan menjadi $80 \%$ sehingga termasuk kategori tinggi.

Kemampuan Berpikir kritis meliputi aspek mengidentifikasi masalah, menganalisis, dan menyimpulkan. Peningkatan persentase ketuntasan pada masing-masing aspek kemampuan berpikir kritis dapat dilihat pada Gambar 2.

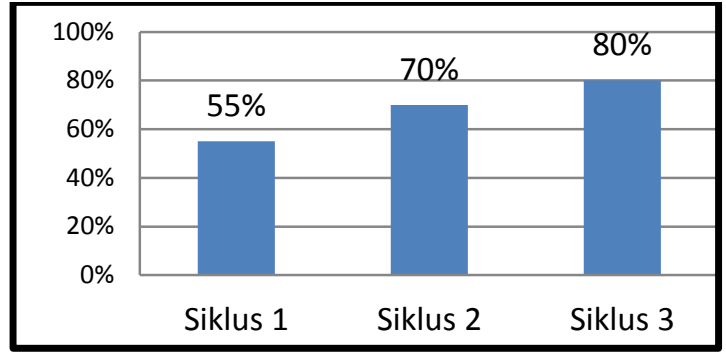

Gambar 2. Persentase Ketuntasan Aspek Kemampuan Berpikir Kritis

Pada siklus I kemampuan siswa dalam mengidentifikasi masalah sebesar 70\%. Pada siklus II, guru mendorong siswa untuk lebih teliti dalam membaca soal dan menuliskan yang diketahui dan ditanyakan. Siswa yang masih kesulitan dalam memahami masalah pun menjadi lebih mudah dalam menuliskan yang diketahui dan ditanyakan dalam soal. Pada tes siklus II persentase ketuntasan menjadi $80 \%$. Pada siklus III siswa sudah terbiasa menuliskan yang diketahui dan ditanyakan, sehingga persentase aspek memahami masalah menjadi $95 \%$.

Hasil tes pada siklus I menunjukkan kemampuan siswa untuk menganalisis hanya sebesar $60 \%$. Ada beberapa siswa masih kesulitan dalam menghubungkan informasi yang relevan untuk menyelesaikan permasalahan pada soal. Dalam pembelajaran siklus II siswa didorong untuk menganalisis permasalahan secara sistematis termasuk memberi penjelasan pada gambar yang digunakan. Hasilnya, pada tes siklus II persentase ketuntasan menjadi $70 \%$. Pada pembelajaran siklus III aspek menganalisis lebih ditekankan pada proses penyelesaian masalah secara sistematis sehingga ketika tes siklus III siswa mampu menghubungkan informasi yang relevan untuk menyelesaikan permasalahan pada soal dengan baik. Hasil tes pada siklus III meningkat menjadi $80 \%$.

Ketuntasan pada aspek menyimpulkan siklus I sebesar 60\%. Siswa masih kesulitan untuk menyusun kesimpulan berdasarkan hasil analisis. Pada siklus II ketuntasan pada aspek menyimpulkan juga masih sebesar $60 \%$. Melalui pembelajaran dengan metode inquiry pada siklus III siswa lebih dibiasakan memberi simpulan dengan lebih baik. Siswa didorong untuk aktif menanggapi hasil diskusi dan membuat kesimpulan secara bersama-sama. Adanya tanggapan dari teman mendorong siswa untuk memperbaiki hasil pekerjaannya baik dalam langkah penyelesaian maupun simpulan yang 
disajikan. Pada tes siklus III ketuntasan aspek menyimpulkan meningkat menjadi $75 \%$.

Peningkatan kemampuan berpikir kritis siswa tersebut tidak terlepas dari penerapan metode inquiry pada pembelajaran tematik integratif. Melalui metode inquiry pada pembelajaran tematik integratif, siswa aktif mengkonstruksi pengetahuannya sendiri berdasarkan pengalaman dan pengetahuan yang telah dimilikinya dengan bimbingan guru. Hal ini didukung oleh peryataan Duron et al., (2006, p. 160) yang menyatakan bahwa pembelajaran yang aktif menjadikan pembelajaran lebih menyenangkan bagi guru dan siswa, dan yang paling penting dapat menyebabkan siswa untuk berpikir kritis.

Kemampuan berpikir kritis tersebut dikembangkan melalui proses inquiry. Kilbane \& Milman (2012, p.244) menyatakan keterlibatan siswa dalam penyelidikan dan penemuan membantu mengembangkan kemampuan berpikir kritis. Proses pencarian informasi memberikan kesempatan kepada siswa untuk mengembangkan kemampuan berpikir kritis.

Peningkatan prestasi belajar siswa meliputi ranah pengetahuan, sikap, dan keterampilan pemecahan masalah. Hasil tes prestasi belajar ranah pengetahuan pada siklus I menunjukkan persentase ketuntasan sebesar $65 \%$. Setelah mengikuti pembelajaran dengan metode inquiry pada siklus II prestasi belajar siswa meningkat. Hal ini dapat dilihat pada hasil tes siklus II yang menunjukkan persentase ketuntasan sebesar $75 \%$. Begitu juga setelah mengikuti pembelajaran pada siklus III, siswa memiliki prestasi belajar dengan kategori Sangat Baik menjadi $80 \%$. Peningkatan persentase ketuntasan prestasi belajar ranah pengetahuan dapat dilihat pada Gambar 3.

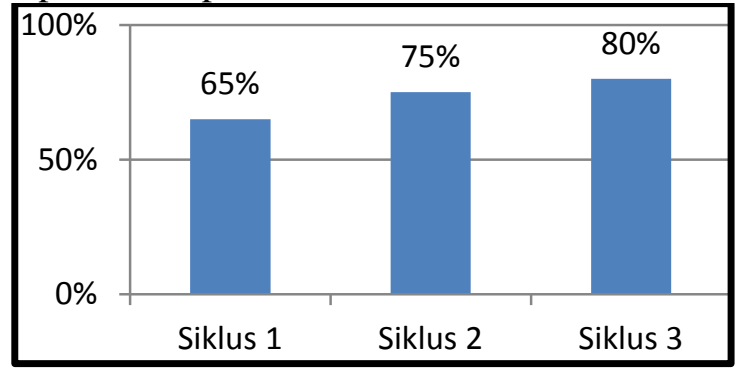

Gambar 3. Persentase Ketuntasan Pengetahuan

Persentase ketuntasan sikap siswa pada setiap siklus juga mengalami peningkatan. Sikap siswa yang dimaksud dalam penelitian ini meliputi aspek rasa ingin tahu, terbuka, kerja sama, dan tanggung jawab. Pada siklus I persentase ketuntasan hanya sebesar $75 \%$ sedang- kan pada siklus II meningkat menjadi $80 \%$. Pada siklus II persentase ketuntasan sebesar $80 \%$ pada siklus III persentase ketuntasan meningkat menjadi $90 \%$. Peningkatan persentase ketuntasan prestasi belajar ranah sikap teerllihat pada Gambar 4.

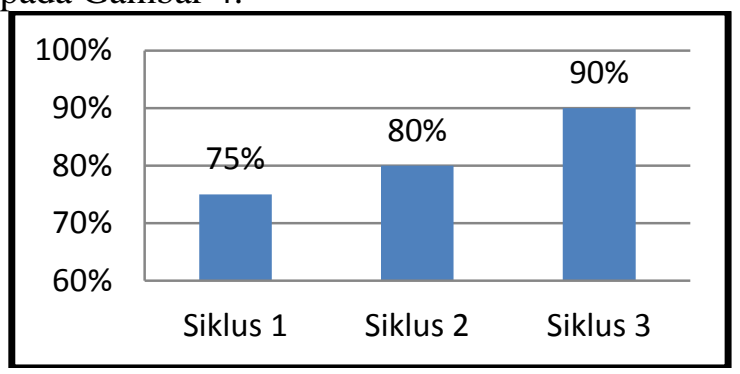

Gambar 4. Persentase Ketuntasan Sikap

Prestasi belajar ranah keterampilan juga mengalami peningkatan. Keterampilan pemecahan masalah meliputi aspek memahami masalah, menyusun rencana, melakukan rencana penyelesaian dan memeriksa kembali.Hasil tes pada siklus I menunjukkan persentase ketuntasan kelas $70 \%$. Pada siklus II rata-rata tes keterampilan mengalami peningkatan menjadi 2,98, dengan persentase ketuntasan kelas $75 \%$. Sedangkan pada siklus III persentase ketuntasan kelas menjadi $80 \%$. Peningkatan persentase ketuntasan prestasi belajar ranah keterampilan dapat dilihat pada gambar 5 .

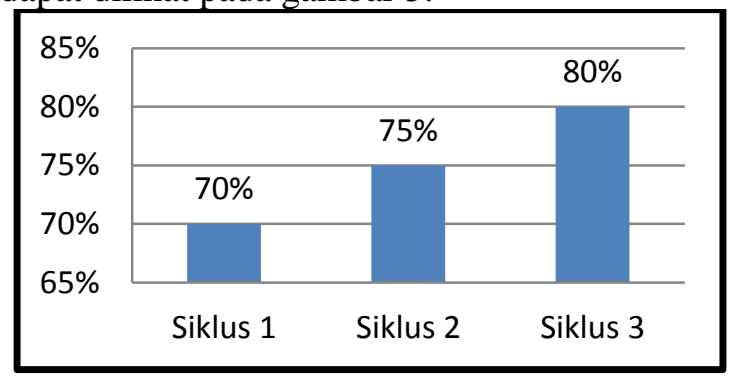

Gambar 5. Persentase Ketuntasan Keterampilan

Meningkatnya prestasi belajar melalui pembelajaran dengan metode inquiry sesuai dengan pendapat Kilbane \& Milman (2012, p.244) menyatakan bahwa melalui pembelajaran dengan metode inquiry siswa juga mengembangkan pengetahuan akademik yang meliputi pemahaman fakta, prinsip, dan konsep dalam konteks pemecahan masalah yang bermakna. Metode pembelajaran inquiry dapat meningkatkan kemampuan akademik yang ditunjukkan dengan pencapaian prestasi belajar.

Metode inquiry dapat meningktakan prestasi belajar. Kindsvatter, et.al. (1996, p.259) menyatakan bahwa dengan metode inquiry konten (materi) dan proses diajarkan pada waktu yang bersamaan. Pemahaman terha- 
dap kompetensi pembelajaran dapat diperoleh melalui proses inquiry itu sendiri.

Melalui pembelajaran inquiry, siswa dapat menemukan pemahaman melalui penyelidikan masalah. Kuhlthau, Maniotes, \& Caspari (2007, p.2) yang menyatakan bahwa inquiry adalah sebuah pendekatan pembelajaran yang digunakan agar siswa dapat menemukan pemahaman tentang pengetahuan melalui penyelidikan masalah dengan berbagai sumber informasi.

\section{Simpulan}

Hasil Penelitian menunjukkan bahwa penerapan Metode inquiry pada pembelajaran tematik integratif dapat meningkatkan kemampuan berpikir kritis siswa kelas IV SD Kasongan Bantul. Peningkatan kemampuan berpikir kritis ditunjukkan dengan persentase ketuntasan kemampuan berpikir kritis yang mencapai $80 \%$ dengan rata-rata kelas 3,12 sehingga masuk dalam kategori tinggi. Aspek-aspek berpikir kritis terdiri atas mengidentifikasi masalah, menganalisis, dan menyimpulkan. Persentase ketuntasan aspek mengidentifikasi masalah mencapai 95\% sehingga masuk kategori sangat tinggi. Persentase ketuntasan aspek menganalisis menjadi $80 \%$ sehingga masuk kategori tinggi. Sedangkan persentase ketuntasan aspek menyimpulkan sebesar $75 \%$ sehingga masuk kategori tinggi.

Metode inquiry pada pembelajaran tematik integratif dapat meningkatkan prestasi belajar matematika siswa kelas IV SD Kasongan Bantul. Peningkatan prestasi belajar matematika siswa tersebut meliputi ranah pengetahuan, sikap, dan keterampilan. Peningkatan prestasi belajar pada ranah pengetahuan ditunjukkan dengan persentase ketuntasan kelas ranah pengetahuan mencapai $80 \%$ dengan rata-rata 3,04 sehingga masuk dalam kategori tinggi. Peningkatan prestasi belajar ranah sikap ditunjukkan dengan persentase ketuntasan ranah sikap mencapai 90\% dengan rata-rata kelas 3,16 sehingga masuk dalam kategori sangat tinggi. sedangkan peningkatan prestasi belajar ranah keterampilan ditunjukkan dengan persentase ketuntasan ranah keterampilan mencapai $80 \%$ dengan rata-rata kelas 3,20 sehingga masuk dalam kategori tinggi.

\section{Daftar Pustaka}

Anindyta, P., \& Suwarjo, S. (2014). Pengaruh problem based learning terhadap keterampilan berpikir kritis dan regulasi diri siswa kelas V. Jurnal Prima Edukasia, 2(2), 209-222. http://doi.org/10.21831/jpe.v2i2.2720

Banchi, H., \& Bell, R. (2008). The Many Levels of Inquiry. Science and Children, 46(2), 26-29. http://doi.org/10.1111/j.1600065X.2008.00760.x.SHP-1

Brown, N., Wilson, K., \& Fitzallen, N. (2007). Using an inquiry approach to develop mathematical thinking. In AARE Annual conference (pp. 1-12). Deakin: Australian Association for Research in Education. Retrieved from http://www.aare.edu.au/publicationsdatabase.php/5320/Using-an-inquiryapproach-to-develop-mathematicalthinking

Duron, R., Limbach, B., \& Waugh, W. (2006). Critical Thinking Framework For Any Discipline. International Journal of Teaching and Learning in Higher Education, 17(2), 160-166. http://doi.org/10.1016/j.nepr.2006.09.004

Dell'Olio, J.M. \& Donk, T. (2007). Models of teaching connecting student learning with standards. Los Angeles: SAGE.

Hosnan. (2014). Pendekatan saintifik dan kontekstual dalam pembelajaran abad 21. Jakarta: Ghalia Indonesia Persada.

Kilbane, C.R. \& Milman, N.B. (2014). Teaching models designing instruction for $21^{\text {st }}$ century learners. New York: Pearson Education, Inc.

Kindsvatter, R., Wilen, W., \& Ishler, M. (1996). Dynamics of effective teaching $3^{\text {th }}$ edition: New York: Longman Publisher.

Kuhlthau, C.C., Maniotes, L.K., \& Caspari A.K. (2007). Guided inquiry: Learning in the $21^{\text {st }}$ century. London: Greenwood Publishing Group, Inc.

Kunandar. (2013). Penilaian autentik suatu pendekatan praktis. Jakarta: PT. Raja Grafindo.

McGregor, D. (2007). Developing thinking; developing learning a guide to thinking skills in education. New York: McGraw Hill Companies. 
McTaggart, $R$. (1991). Action research a short modern history. New York: McGraw Hill Companies.

Muijs, D. \& Reynolds, D. (2005). Effective teaching effedence and practice. London: SAGE Publishing.

Orlich, D.C., Harder, R.J., \& Callahan, R.C., et.al. (2009). Teaching strategies a guide to effective instruction $9^{\text {th }}$. New York: Houghton Mifflin Company.

Schneider, V. (2002). Critical Thinking in the elementary classroom: Problem and solutions. Educators Publishing Service, Oct, 1-3.

Schunk, D.H. (2008). Learning Theories: An educational perpektif $\left(5^{\text {th }}\right.$ ed).Upper Saddle River: Pearson Educational Inc.
Setyawan, W. W., \& Mustadi, A. (2015). Pengembangan SSP tematik-integratif untuk membangun karakter disiplin dan kreatif siswa kelas I SD. Jurnal Prima Edukasia, $\quad 3(1), \quad 108-119$. http://doi.org/10.21831/JPE.V3I1.4072

Stiggins, R.J \& Chappuis, J. (2011). An introduction to student-involved assessment for learning. New York: Pearson.

Wangid, M. N., Mustadi, A., Erviana, V. Y., \& Arifin, S. (2014). Kesiapan guru SD dalam pelaksanaan pembelajaran tematikintegratif pada kurikulum 2013 di DIY. Jurnal Prima Edukasia, 2(2), 175-182. http://doi.org/10.21831/jpe.v2i2.2717

Winkel,W.S. (2014). Psikologi pengajaran. Yogyakarta: Sketsa. 